\title{
Editorial: Applied Uses of Ancient DNA
}

\author{
Nicolas J. Rawlence ${ }^{1 *}$, Michael Knapp ${ }^{2,3}$, Michael D. Martin ${ }^{4}$ and Nathan Wales ${ }^{5}$ \\ ${ }^{1}$ Otago Palaeogenetics Laboratory, Department of Zoology, University of Otago, Dunedin, New Zealand, ${ }^{2}$ Department of \\ Anatomy, University of Otago, Dunedin, New Zealand, ${ }^{3}$ Coastal People Southern Skies Centre of Research Excellence, \\ University of Otago, Dunedin, New Zealand, ${ }^{4}$ Department of Natural History, NTNU University Museum, Norwegian \\ University of Science and Technology (NTNU), Trondheim, Norway, ${ }^{5}$ Department of Archaeology, University of York, York, \\ United Kingdom
}

Keywords: ecological restoration, human history, method development, museums, taxonomy

\section{Editorial on the Research Topic}

\section{Applied Uses of Ancient DNA}

The advent of ancient DNA research 35 years ago, with the publication of DNA sequences from the extinct quagga (Higuchi et al., 1984), changed the way scientists look at ecology and evolution. For the first time, evolution could be studied in "real-time" rather than relying on contemporaneous samples to study the past. The invention and continued development of highthroughput sequencing technologies (Marguiles et al., 2005) led to further technological advances in the field, making the sequencing of whole ancient genomes possible (e.g., Van der Valk et al., 2021), in turn allowing macro- and micro-evolutionary processes to be examined in ever finer detail (Mitchell and Rawlence, 2021). Ancient DNA, combined with archaeological, paleontological and paleoecological approaches, has been shown to be critical to the understanding of how ecosystems function, and how these processes may play out into the future (Stiller et al., 2010; Rawlence et al., 2012; Knapp, 2019; Thomas et al., 2019).

While the majority of ancient DNA research is focused on big-picture, curiosity driven or "blue skies" questions (e.g., Slon et al., 2018), there is a growing appreciation that ancient DNA can be used for more applied aspects of science. Metcalf et al. (2012) used ancient DNA from cutthroat trout (Oncorhynchus clarkii) museum specimens, and historical records, to document recent human-driven extinctions, previously cryptic lineages, translocations and range fluctuations, to highlight the importance of historical records for informing evidence-based conservation management. Increasingly, applied applications of ancient DNA include conservation paleontology (e.g., Shepherd et al., 2012), conservation archaeogenomics (Hofman et al., 2015), elucidating the impacts of over-harvesting (Oosting et al., 2019), museum collections management (e.g., Boessenkool et al., 2010), ecological restoration (e.g., Wilmshurst et al., 2014), tracking the history of invasive species (e.g., Martin et al., 2014), biosecurity (e.g., Di Donato et al., 2018), and taxonomy (e.g., Forin et al., 2018).

In this Research Topic, we have compiled 13 different contributions from across the field of applied ancient DNA pertaining to museum collections, ecological restoration, human and cultural history, and methodological development. Museum specimens are increasingly valued and sought after in genetic research (e.g., McCormack et al., 2017; Nakahama, 2020). Verry et al. highlight the importance of accurate specimen data when using historical records to inform

Rawlence NJ, Knapp M, Martin MD and Wales N (2021) Editorial: Applied

Uses of Ancient DNA.

Front. Ecol. Evol. 9:679489.

doi: 10.3389/fevo.2021.679489 conservation translocation decisions, where deliberate falsification or poor record keeping was 
common (e.g., Boessenkool et al., 2010; Miskelly, 2012; Rawlence et al., 2014). Casteneda-Rico et al. resolve the controversial taxonomy of the critically endangered Puebla deer mouse (Peromyscus mekisturus) using historical specimens, with consequent conservation management implications, further highlighting the importance of archival specimens when contemporary individuals are rare or non-existent. Sarkissian et al. demonstrate that mollusc shells, which are ideal indicators of environmental change and have been seemingly ignored by the ancient DNA community until recently, can in fact preserve ancient DNA up to $\sim 100,000$ years old.

Biodiversity cannot be conserved and ecosystems restored effectively without knowledge of the pre-disturbance ecological and genetic landscape. This is especially true in tropical ecosystems, which are undergoing collapse (Barlow et al., 2018). Dommain et al. show it is possible to retrieve sedimentary ancient DNA from swamps in tropical Uganda, which can provide an additional tool to the fossil and historical record, especially where these are rare.

Ancient DNA has also allowed scientists and archaeologists to better understand our past, often in ways that are not previously discernible from the archaeological record. Vai et al. review the potential applications and limitations of experimental and computational methodologies for kinship determination. Wasef et al. show that hypothesized inequalities in Australian Aboriginal burial practices based on status, sex, and age, may instead relate to local versus non-local origins. In their review, Przelomska et al. argue a multidisciplinary approach offers an unprecedented insight into how plants and humans evolved together, how plants were used, and how ancient DNA can play an important role in the sustainability of the world's food system. Finally, Arriola et al. review the field of palaeomicrobiology which has provided a unique window to the evolution of (non)pathogenic microbes, many of which have had a profound impact on human history, and what

\section{REFERENCES}

Barlow, J., Franca, F., Gardner, T. A., Hicks, C. C., Lennox, G. D., Berenguer, E., et al. (2018). The future of hyperdiverse tropical ecosystems. Nature 559, 517-526. doi: 10.1038/s41586-018-0301-1

Boessenkool, S., Star, B., Seddon, P. J., and Waters, J. M. (2010). Lost in translation of deliberate falsification? Genetic analyses reveal erroneous museum data for historic penguin specimens. Proc. B 277, 1057-1064. doi: $10.1098 / \mathrm{rspb} .2009 .1837$

Di Donato, A., Filippone, E., Ercolano, M. R., and Frusciante, L. (2018). Genome sequencing of ancient plants remains: findings, uses and potential applications for the study and improvement of modern crops. Front. Plant Sci. 9:441. doi: $10.3389 /$ fpls.2018.00441

Forin, N., Nigris, S., Voyron, S., Girlanda, M., Vizzini, A., Casadoro, G., et al. (2018). Next generation sequencing of ancient fungal specimens: the case of the Saccardo Mycological Herbarium. Front. Ecol. Evol. 6:129. doi: $10.3389 /$ fevo.2018.00129

Higuchi, R., Bowman, B., Freiberger, M., Ryder, O. A., and Wilson, A. C. (1984). DNA sequences from the quagga, and extinct member of the horse family. Nature 312, 282-284. doi: $10.1038 / 312282 \mathrm{a} 0$

Hofman, C. A., Rick, T. C., Fleischer, R. C., and Maldonado, J. E. (2015). Conservation archaeogenomics: ancient DNA and biodiversity in the Anthropocene. Trends Ecol. Evol. 30, 540-549. doi: 10.1016/j.tree.2015.06.008 the future may hold for this burgeoning area of ancient DNA research.

Methodological development is an important part of applied ancient DNA research, as the technique is pushed to its limits (e.g., Van der Valk et al., 2021). The methodological contributions to this Research Topic are no exception, ranging from the application of hybridization capture techniques to forensic science (Young et al.) to developing more accurate algorithms for taxonomic assignment of sedimentary ancient DNA data (Cribdon et al.), and reconstructing signatures of methylation from DNA damage in ancient botanical remains (Wagner et al.), to improving the reference-alignment of DNA sequences derived from ancient genomes and methylomes (Poullet and Orlando), and finally the development of an archival and management system for ancient DNA data (Dolle et al.).

With funding bodies, and the public, increasingly interested in the expected real-world impacts that will justify the costs of scientific research, practical applications of ancient DNA become increasingly important.

\section{AUTHOR CONTRIBUTIONS}

NJR, MK, MDM, and NW contributed to writing and editing. All authors contributed to the article and approved the submitted version.

\section{FUNDING}

NJR was supported by a Royal Society of New Zealand Marsden FastStart grant (Grant no. 16-UOO-096). MK was supported by a Royal Society of New Zealand Rutherford Discovery Fellowship (Grant no. 14-UOO-007). MDM was supported by the Research Council of Norway (Award 287327). NW was supported by the European Research Council Horizon 2020 Research and Innovation Programme (Grant no. 842577).
Knapp, M. (2019). From a molecules' perspective - contributions of ancient DNA research to understanding cave bear biology. Hist. Biol. 31, 442-447. doi: 10.1080/08912963.2018.1434168

Marguiles, M., Egholm, M., Altman, W. E., Attiya, S., Bader, J. S., Bemben, L. A., et al. (2005). Genome sequencing in microfabricated high-density picolitre reactors. Nature 437, 376-380. doi: 10.1038/nature03959

Martin, M. D., Zimmer, E. A., Olsen, M. T., Foote, A. D., Gilbert, M. T. P., Brush, G. S., et al. (2014). Herbarium specimens reveal a historical shift in phylogeographic structure of common ragweed during native range disturbance. Mol. Ecol. 23, 1701-1716. doi: 10.1111/mec.12675

McCormack, J. E., Rodriguez-Gomez, F., Tsai, W. L. E., and Faircloth, B. C. (2017). Transforming museum specimens into genomic resources. In: Webster, M. S. (ed) The extended specimen: emerging frontiers in collections based ornithological research. Stud. Avian Biol. 50, 143-156.

Metcalf, J. L., Stowell, S. L., Kennedy, C. M., Rogers, K. B., McDonald, D., Keepers, J. E. K., et al. (2012). Historical stocking data and 19th Century DNA reveal human-induced changes to native diversity and distribution of cutthroat trout. Mol. Ecol. 21, 5194-5207. doi: 10.1111/mec.12028

Miskelly, C. M. (2012). Discovery and extinction of the South Island snipe (Coenocorypha iredalei) on islands around Stewart Island. Notornis 59, 15-31.

Mitchell, K. J., and Rawlence, N. J. (2021). Examining natural history through the lens of palaeogenomics. Trends Ecol. Evol. 36, 258-267. doi: $10.1016 /$ j.tree.2020.10.005 
Nakahama, N. (2020). Museum specimens: an overlooked and valuable material for conservation genetics. Ecol. Res. 36, 13-23. doi: 10.1111/1440-1703.12181

Oosting, T., Star, B., Barrett, J. H., Wellenreuther, M., Ritchie, P. A., Rawlence, N. J. (2019). Unlocking the potential of ancient fish DNA in the genomic era. Evol. Appl. 12, 1513-1522. doi: 10.1111/eva.12811

Rawlence, N. J., Kennedy, M., Waters, J. M., and Scofield, R. P. (2014). Morphological and ancient DNA analyses reveal inaccurate labels on two of Buller's bird specimens. J. Roy. Soc. New Zeal. 44, 163-169. doi: 10.1080/03036758.2014.972962

Rawlence, N. J., Metcalf, J., Wood, J. R., Worthy, T. H., Austin, J. A., Cooper, A. (2012). The effect of climate and environmental change on the megafaunal moa of New Zealand in the absence of humans. Quat. Sci. Rev. 50, 141-153. doi: 10.1016/j.quascirev.2012.07.004

Shepherd, L. D., Worthy, T. H., Tennyson, A. J. D., Scofield, R. P., Ramstad, K. M., Lambert, D. M. (2012). Ancient DNA analyses reveal contrasting phylogeographic patterns amongst kiwi (Apteryx spp.) and a recently extinct lineage of spotted kiwi. PLoS ONE 7:e42384. doi: 10.1371/journal.pone.0042384

Slon, V., Mafessoni, F., Vernot, B., de Filippo, C., Grote, S., Viola, B., et al. (2018). The genome of the offspring of a Neanderthal mother and a Denisovan father. Nature 561, 113-116. doi: 10.1038/s41586-018-0455-x

Stiller, M., Baryshnikov, G., Bocherens, H., Grandal d'Anglade, A., Hilpert, B., Münzel, S. C., et al. (2010). Withering away - 25,000 years of genetic decline preceded cave bear extinction. Mol. Biol. Evol. 27, 975-978. doi: $10.1093 / \mathrm{molbev} / \mathrm{msq} 083$
Thomas, J. E., Carvalho, G. R., Haile, J., Rawlence, N. J., Martin, M. D., Ho, S. Y. W., et al. (2019). Demographic reconstruction from ancient DNA supports rapid extinction of the Great Auk. eLife 8:e47509. doi: 10.7554/ eLife.47509.sa2

Van der Valk, T., Pecnerova, P., Diez-del-Molino, D., Bergstrom, A., Oppenheimer, J., Hartmann, S., et al. (2021). Million-year-old DNA sheds light on the genomic history of mammoths. Nature 591, 265-269. doi: 10.1038/s41586021-03224-9

Wilmshurst, J. M., Moar, N. T., Wood, J. R., Bellingham, P. J., Findlater, A. M., Robinson, J. J., et al. (2014). Use of pollen and ancient DNA as conservation baselines for offshore islands in New Zealand. Conserv. Biol. 28, 202-212. doi: $10.1111 /$ cobi.12150

Conflict of Interest: The authors declare that the research was conducted in the absence of any commercial or financial relationships that could be construed as a potential conflict of interest.

Copyright (c) 2021 Rawlence, Knapp, Martin and Wales. This is an open-access article distributed under the terms of the Creative Commons Attribution License (CC BY). The use, distribution or reproduction in other forums is permitted, provided the original author(s) and the copyright owner(s) are credited and that the original publication in this journal is cited, in accordance with accepted academic practice. No use, distribution or reproduction is permitted which does not comply with these terms. 